\title{
Anatomical characteristics and hydrologic signals in tree-rings of oaks (Queraus robur L.)
}

\section{Jožica GRIČAR ${ }^{1 *}$, Martin DE LUIS ${ }^{2}$, Polona HAFNER ${ }^{1}$, Tom LEVANIČ ${ }^{1}$}

${ }^{1}$ Slovenian Forestry Institute, Vecna pot 2, SI-1000 Ljubljana, Slovenia

${ }^{2}$ Departamento de Geografía y O.T., C/Pedro Cerbuna 12, Universidad de Zaragoza, ES-50009 Zaragoza, Spain

*Corresponding author:

Email: jozica.gricar@gozdis.si

Phone number: 386-1-200-78-00

Fax number: 386-1-257-35-89

For submission to: Trees
This is an Authors's Accepted manuscript of an article published in Gričar J. et al. 2013. Anatomical characteristics and hydrologic signals in tree-rings of oaks (Quercus robur. Trees, 27, 6: 1669-1680 doi: $10.1007 /$ s00468-013-0914-9

\section{Author Contribution Statement}

J.G. - wrote the paper, prepared the cross-sections and performed the wood-anatomical analysis, M.DL. developed the concept of the paper, carried out statistical analysis, wrote statistical parts of the paper and prepared figures, P.H. - collected the samples, as well as hydrological and climate data, T.L. - designed the study, selected the plots and trees.

\section{Key Message}

Anatomical characteristics and hydrologic signals in tree-rings of oaks from areas with regular floodings may vary, even within the same forest stand, and largely depends on the micro-environmental conditions.

Word count of the abstract: 244

Total word count of the main body of the text: 4869

Number of references: 56

Number of tables: 2

Number of figures: 7 
Q. robur decline in European floodplain forests in recent years seems to be strongly associated with the deteriorating hydrological regime. We investigated the influence of the Krka River flow on tree-ring patterns of Q. robur from the Krakovo floodplain forests (Slovenia) in order to assess the effect of micro-location conditions on hydrologic signals in wood-anatomical characteristics. We selected two groups of $Q$. robur trees growing at nearby locations with different hydrologic conditions, resulting in frequent autumn and spring flooding at the wetter site $(=\mathrm{W}$ oaks $)$ but no flooding at the other, drier site $(\mathrm{D}=$ oaks $)$. We found differences between the two groups in the anatomical structure of tree-rings; however, ring width proved to be the main variable determining the anatomical structure of oak wood. D and W oaks responded differently to the Krka River flow in the studied period. Radial growth of D oaks was negatively influenced by spring flow, but positively influenced by minimum summer flow. In $\mathrm{W}$ oaks, ring width was positively correlated with mean summer flow. Thus, environmental information stored in wood anatomical features may vary, even within the same forest stand, and largely depends on the micro-environment. Reduced wood increments of D oaks suggest that growth conditions are less favourable, implying a link between the health state of oaks from lowland forest and hydrologic conditions. Trees intended for hydrologic reconstruction must therefore be carefully selected in order to avoid the possibility of error and potential loss of information.

\section{Keywords}




\section{Introduction}

In Slovenia, oaks (Quercus robur L. and Quercus sessiliflora Salisb.) are economically very important wood species, representing about $7 \%$ of the entire wood stock (Gozdnogospodarski etc. 2006). In relation to $Q$. robur, the lowland forest area has been shrinking, due to human settlement in the past, intensive and unplanned silvicultural and agricultural exploitation of the land and conflicts of interest, so only a few lowland oak forest stands have managed to survive (Kadunc 2010). In addition, as in many European countries (e.g., Klimo and Hager 2001), a trend of decreasing vitality of $Q$. robur has been observed in most sites in recent decades (Čater et al. 2001). One of the main reasons for this situation in Slovenia is ascribed to decreasing ground water levels due to changes in climatic conditions and unsuitable artificial melioration of land for agricultural purposes, for which numerous drainage ditches were excavated in the $19^{\text {th }}$ century (Čater et al. 2001). The most obvious response of Q. robur to the changing environmental (hydrologic) conditions is seen in its decreased vitality (e.g., Hager and Buchleitner 2001; Vukelić and Rauš 2001), resulting in reduced wood increment (Levanič et al. 2011), which is closely related to the structure of wood and its quality (Rao et al. 1997).

In addition to major economic consequences in these areas, ecological issues associated with decreasing vitality of $Q$. robur stands cannot be neglected. The many local oak tree-ring chronologies from various sites of Slovenia (Čufar and Levanič 1999a, b, Čufar et al. 2008) differ greatly among each other, particularly in the case of $Q$. robur from lowland sites, where tree growth is often influenced by micro-site hydrologic conditions (Čater 2003; Čater and Batič 2006; Čater and Levanič 2004; Levanič 1993; Levanič et al. 2011). However, tree-ring width (TRW) is only one environmental proxy, whereas others still remain to be explored. In this respect, the use of other proxies, such as wood anatomical variables, have proved to be particularly promising (e.g., Fonti et al. 2010).

Q. robur is a regular constituent of floodplain forests and is generally considered to be one of the most flood-tolerant Quercus species with respect to growth and survival (Prpić 2003; Schmull and Thomas 2000). However, knowledge of its growth response in such environments is scarce (e.g., Leuschner et al. 2002; SassKlaassen and Hanraets 2006). Due to changes in the hydrologic regime, the groundwater level and water supply might differ even in the same forest stand, which raises the question of the extent to which micro-location conditions affect tree-ring patterns of $Q$. robur. This could be an important factor for assessing the environmental sensitivity of $Q$. robur from floodplain forests in Slovenia.

To test this hypothesis, we selected two groups of adult $Q$. robur trees, growing at nearby locations with different hydrologic conditions. The wetter site (= W oaks) is characterized by frequent autumn and spring flooding, 
whereas no flooding occurs at the drier site (= D oaks). In order to reduce any geographical differences in climate affecting the trees under study to a minimum, the sites were chosen in the same forest stand in Krakovo forest, which is in some parts often flooded by the Krka River. In particular, aims of the study were to: (1) evaluate if TRW and their anatomical characteristics (including latewood) of $Q$. robur differ in flooded and unflooded areas. For this purpose, we used 10 different wood-anatomical variables for the period 1970-2008; (2) to assess if selected 10 anatomical variables show the same pattern of temporal variation and if they contain complementary or redundant information; (3) to determine if morphological characteristics of the selected variables are related to the Krka River flow.

\section{Material and methods}

\section{Study site characteristics}

The research was carried out in Krakovo Querco robori-Carpinetum mixed forest, Slovenia (45 $54^{\prime} \mathrm{N}, 1525^{\prime} \mathrm{E}$, elevation $150 \mathrm{~m}$ ), which is the largest lowland oak forest complex in Slovenia and is mainly composed of Quercus robur, Carpinus betulus and Alnus glutinosa in combination with Tilia sp., Prunus avium, Acer campestris, Fraxinus angustifolia and Ulmus campestris tree species.

The appearance of the specific forest association is mostly determined by microtopography and soil properties, which, to a large degree, influence runoff, distribution and water movement into the soil. Hydromorphic soils, such as pseudogley and gleysoils (amphygley), on pleistocene clays and loams with low infiltration capacity prevail. The occurrence of different forms of deposits is responsible for the difference in permeability of the soil surface, which in turn affects groundwater level (Accetto 1975). In rainy periods, water can temporarily stagnates on the surface and slowly evaporates or absorbs into the soil. The area may remain flooded for weeks. However, due to low infiltration capacity of this soil type, most of the rainwater on slightly inclined slope or a bit higher elevation can runoff the surface before the soil absorbs it. This could negatively affect the hydrologic conditions at such micro-locations (Čater et al. 2001). Differences in the depth of the groundwater table at the same surface level can be up to $90 \mathrm{~cm}$ within a horizontal distance of $2 \mathrm{~m}$. The level of water table varies during the year, being very high in the fall, winter and early spring (Žibert 2006).

In addition to the groundwater level and rainwater, which may stagnate on the low permeable soil surface, frequent autumn and spring floodings of the Krka River, the main river in this area, significantly affect hydrologic conditions in the Krakovo forest. The Krka River belongs to the Karst Rivers. It has a rain-snow regime, with runoff peaks in April and November, and minima in August and January. The Krka River has numerous small 
tributaries and regularly floods, especially in spring and autumn. Data for minimal (Qnp), average (Qs) and maximal (Qvp) monthly (Figure 1) and annual (Figure 2) rate of flow for the Krka River for the period 1970-2008 were obtained from the Environmental Agency of the Republic of Slovenia within the Ministry of the Environment and Spatial Planning.

\section{Figure 1}

Figure 2

The study area is characterized by sub-pannonian continental climate. About $70 \%$ of all precipitation thus falls during the growing season (March to October) and a very small amount in winter. The mean annual temperature is $10.1^{\circ} \mathrm{C}$ (range $8.6-12.0^{\circ} \mathrm{C}, \mathrm{T}_{\mathrm{Jan}}=-0.1^{\circ} \mathrm{C},-\mathrm{T}_{\mathrm{Jul}}=20.1^{\circ} \mathrm{C}$ ) and total annual precipitation $1149 \mathrm{~mm}$ (range 827-1405 mm, $\mathrm{P}_{\mathrm{Jan}}=51.3 \mathrm{~mm}, \mathrm{P}_{\mathrm{Aug}}=126,9 \mathrm{~mm}$ ), as calculated from the 1970-2008 climate dataset from the nearby Novo mesto climate station of the Environmental Agency of the Republic of Slovenia. The station is located approximately $20 \mathrm{~km}$ from the forest site $\left(45^{\circ} 48^{\prime} \mathrm{N}, 15^{\circ} 11^{\prime} \mathrm{E}\right.$; altitude $\left.220 \mathrm{~m}\right)$.

\section{Tree selection, sampling and anatomical observations}

Penduculate oak (Quercus ruber L.) trees were sampled at two research plots in a Krakovo forest stand. In order to reduce any geographical differences in climate affecting the trees under study to a minimum, the research plots were only about $600 \mathrm{~m}$ apart and belong to the same forest association, but differ in the hydrologic conditions. Oaks growing on the first plot were exposed to occasional flooding (= $\mathrm{W}$ oaks), especially in autumn and spring periods, whereas in the second plot, flooding does not occur (= D oaks). The reason could be in a slightly inclined surface and a bit higher elevation, which prevent the retention of the surface water.

Six dominant or codominant trees were selected on each plot; a total of 12 trees were thus analysed. Selected trees were 80-100 yeas old, with DBH 30-60 cm, without any visible mechanical injures of stems or roots. During winter 2008-2009, we took $1 \mathrm{~cm}$ wide cores about $1.3 \mathrm{~m}$ above the ground from each of the trees in order to prepare microscopic slides. The material was fixed in formalin-ethanol-acetic acid solution (FEA) and dehydrated in a graded series of ethanol $(30 \%, 50 \%$ and $70 \%)$ after one week. Each core was cut exactly at the growth ring boundary into pieces about 5-6 cm long, so that they could be placed on microscope lides. Permanent transverse sections of $25 \mu \mathrm{m}$ in thickness were prepared on a "G.S.L. 1" Sledge microtome $\left({ }^{\oplus}\right.$ Gärtner and 
Schweingruber; Design and production: Lucchinetti, Schenkung Dapples, Zürich, Switzerland) with disposable blades. Sections were stained with safranin (Merck, Darmstadt, Germany) (0.5\% in $95 \%$ of ethanol) and mounted in Euparal and observed under an Olympus BX51 (Tokyo, Japan) light microscope and analysed with the Nikon NIS-Elements Basic Research v.2.3 image analysis system (Tokyo, Japan).

Oak ring-porous wood is composed of several types of cells, which are specialized to accomplish their function; vessels, vasicentric tracheids, libriform fibers and axial and ray parenchyma cells (Carlquist 1988). All vessels are sheathed by thin-walled vasicentric tracheids and are responsible for water transport. Most of the EW area is occupied by vessels that can be seen with the naked eye in the transverse plane (diameters more than 200 $\mu \mathrm{m}$ ), whereas vessels in LW are much smaller (diameter around $50 \mu \mathrm{m}$ ). $\mathrm{LW}$ vessels are distributed solitarily or in wide growth rings, as radially orientated groups, which alternate with groups of thick-walled libriform fibers. Mechanical support is mainly provided by libriform fibers. The distribution of axial parenchyma is either diffuse or in uniseriate diagonal and tangential bands. Oak has two types of rays; uniseriate and broad (up to 30 cells), which are also clearly visible at macroscopic level (Figure 3).

We analysed the wood structure of the last 39 rings (1970-2008) in order to avoid juvenile wood, because its anatomical structure and TRW significantly differ from adult wood. In each of the tree-rings, we determined the measurement frame, in which we analysed various anatomical characteristics in early- (EW) and latewood (LW) (Table 1). The tangential width of the frame was $4 \mathrm{~mm}$ and the radial width was the width of the tree-ring (Figure 3); however, if multi-layered rays were present, we subtracted their area from the measured area. Visual inspection revealed that the anatomical structure of tree-rings of similar width differed in $\mathrm{W}$ and D oaks (Figure $4)$.

\section{Table 1}

Figure 3

\section{Figure 4}

\section{Anatomical characterization of tree rings of $W$ and $D$ oaks}

Repeated measures analysis of variance (R-M ANOVA) was used to test for differences between W and D oaks in all the 10 measured anatomical variables. The common period 1970-2008 was used for this analysis. Normal 
distribution and uniformity of variance of each analysed variable was verified using the Shapiro-Wilk W test and Levene test, respectively (Quinn and Keough 2002).

\section{Influence of river flow on tree growth and anatomical characteristics}

The individual measured anatomical series were standardized in the ARSTAN program (Cook and Holmes 1986) by removing long-term trends using a negative exponential function followed by a cubic smoothing spline with a $50 \%$ cut-off frequency and a response period of 30 years. An autocorrelation filter was applied to the detrended series to remove correlations between consecutive measurements and to obtain a residual series containing only high frequency variations in year-to-year series, which are expected to be mainly related to year-to-year environmental variability. The indexed residual series were then averaged using a biweight robust mean to obtain, both for $\mathrm{D}$ and $\mathrm{W}$ oaks, residual chronologies of each of the 10 analyzed variables.

The common period 1970-2008 was then also considered for multivariate analysis in order to identify common modes of variability in the obtained residual chronologies. Principal component analysis (PCA) of the covariance matrix of the residual chronologies was used for grouping series with similar year-to-year variations. PCA was conducted using at the same time datasets of anatomical variables of $\mathrm{W}$ and $\mathrm{D}$ oaks consisting of 20 variables in total (10 for each group). These components were rotated orthogonally according to the VARIMAX criterion to redistribute the final explained variance and to obtain more stable and robust patterns. The most representative principal components were selected and the weighting components (rotated component loadings) were examined to identify the pattern of association of each chronologies with each component (Kaiser 1992). Correlation functions between PCA and river flow data were calculated using the DendroClim2002 program (Biondi and Waikul 2004), whereby the obtained significant PCA eigenvectors were the dependent variables, while the independent variables were the seasonal and annual series of flow data.

\section{Results}

\section{Comparison of anatomical parameters in tree-rings of $W$ and $D$ oaks}

Average values and standard deviation of TRW and measured wood-anatomical variables of W and D oaks are presented in Table 2, whereas the time series of their mean values and standard errors for both groups for the period 1970-2008 are shown in Figure 5. R-M ANOVA confirmed that differences between the two groups exist in 5 of the 10 analized variables (Figure 5). 

(average ring width $=1196.31 \mu \mathrm{m})($ Table 2). Average radial and tangential diameters of EW vessels and consequently their cross-sectional area did not differ between the two groups. Average tangential diameter was smaller than the radial one (for $15 \mu \mathrm{m}$ in D oaks and $56 \mu \mathrm{m}$ in $\mathrm{W}$ oaks, respectively) and average EW vessel area was around $72000 \mu \mathrm{m}^{2}$ in both groups. The proportion of the conductive area in the EW was higher in D oaks $(50.09 \%)$ than in W oaks $(46.07 \%)$, although the number of EW vessels in the EW area did not differ between the two groups (Table 2). Since the proportion of LW was higher in W oaks (61.71\%) than in D oaks (42.38 \%), the number and total area of EW vessels per measured area was consequently lower. The proportion of vessels in LW did not differ between the groups.

Table 2

Figure 5

\section{Common and uncommon temporal patterns in measured anatomical variables}

PCA analysis revealed differences in year to year dynamics among different wood-anatomical characteristics and between $\mathrm{W}$ and D oaks. Anatomical characteristics and the relation among the measured variables can be described by four components that together explained $77.2 \%$ of the total variance. PCA analysis demonstrated that the selected anatomical variables in $\mathrm{W}$ and D oaks significantly differed in their temporal patterns. Two components of the PCA (PC1 and PC3) were mainly related to D oaks and the other two (PC2 and PC4) to W oaks (Figure 6). In both oak groups, TRW and the proportion of LW were positively related (PC1 for D oaks and PC2 for W oaks, respectively). These two anatomical variables were, on the other hand, negatively related to the following anatomical parameters: conductive area of EW vessels and EW vessel density, and in the case of D oaks (PC1) also to the share of vessels in LW (Figure 6a and b). Furthermore, in both groups were tangential and radial dimensions of EW vessels positively related (PC3 for D oaks and PC4 for W oaks, respectively) and consequently also average EW vessel area (Figure $6 \mathrm{c}$ and d). These variables were negatively related to EW vessel density, so that high EW vessel density corresponds to lower EW vessel area. To summarize, we found a statistically significant difference between the two groups of oaks in the following anatomical variables: TRW, conductive area of EW vessels, conductive area in EW, EW vessel density and LW proportion. 
Relation between the measured anatomical variables in each of the studied oak groups and the Krka River flow

Correlation between PCA components and the Krka River flow data at annual and seasonal (from previous autumn to summer) time scales are presented in Figure 7. PC1 and PC3 were mainly related to D oaks whereas PC2 and PC4 to W oaks. Anatomical variables of D oaks linked to PC1 were positively related to spring (mainly maximum) flow and negatively to summer minimum flow, indicating that tree-rings and latewood were wider if spring flow of the Krka River was lower and minimum summer flow was higher. On the contrary were conductive area of EW vessels and EW vessel density higher if spring flow was higher and summer flow lower (Figure 7a). Anatomical variables of W oaks linked to PC2 were negatively related to the (mean) summer flow showing its positive relation with TRW and latewood widths (LWW), but negative with conductive area of EW vessels, EW vessel density and the share of vessels in LW (Figure 7b).

We found no relation of PC3 (D oaks) and PC4 (W oaks) with the Krka River flow data, suggesting that in both groups temporal variabilty patterns of the wood-anatomical variables expressed with these two PC components (i.e., tangential and radial dimensions of EW vessels, average EW vessel area and EW density) were not related with the Krka River flow and were probably influenced by other environmetal (climatic) factors (Figure $7 \mathrm{c}$ and $\mathrm{d})$.

Figure 7

\section{Discussion}

Comparison of anatomical structure in xylem of W and D oaks

The properties of oak wood are closely related to TRW (e.g., Gasson 1987; Leal et al. 2007, 2008; Rao et al. 1997). Studies on within-tree-variation of wood properties in a radial direction in different oak species have shown that cambial age has an influence on TRW, EW vessel diameter, proportion of fibre, vessel and axial parenchyma in LW and specific gravity (Gasson 1987; Lei et al. 1996). Since cambial age explains more of the variation in wood density than does TRW, although TRW declines with cambial age (Lei et al. 1996; Zhang and Zhong 1991), we excluded the juvenile portion of wood from our analysis.

Tree-rings of W oaks were significantly wider than in D oaks, with a lower proportion of EW. It is well known that in ring-porous oak, LWW tends to increase with increasing TRW, whereas the width of EW (EWW) 
remains more or less constant (Lebourgeois et al. 2004; Lei et al. 1996; Phelps and Workman 1994; Rao et al. 1997). More precisely, Zhang (1997) noted that with increasing TRW, LWW increases almost linearly, while EWW increases a little at first, but tends to be constant (about $1 \mathrm{~mm}$ ) when TRW is wider than $3 \mathrm{~mm}$. Since the anatomical structure of EW and LW is very different, their densities also vary, being for about $30 \%$ higher in LW than in EW (Guilley et al. 1999).

We found differences in the anatomical structure of tree-rings in W and D oaks; however, in both groups, anatomical structure of the oak wood proved to be closely related to TRW. In addition to EW proportion, TRW negatively influence the share of total EW conductive area and EW vessel density and, in the case of D oaks, also the proportion of the conductive area in LW, which is in line with the findings of other authors (e.g., Gasson 1987; Phelps and Workman 1994; Rao et al. 1997). The total conductive area in EW was slightly higher in the D oaks, which can be explained by the smaller share of EW in narrow rings, which contain a lower number of vessel rows. It has also been observed in other ring-porous species that in wider rings the proportion of EW vessels with smaller diameters increases, thus reducing the mean EW vessel area (Eilmann et al. 2009; Fonti and García-González 2004; Tardif and Conciatori 2006).

Most studies analysing wood anatomical features have focused primarily on the structure of EW (more specifically EW vessels), while the structure of LW has only rarely been examined (e.g., Eilmann et al. 2006; Phelps and Workman 1994). Our study shows that the proportion of conductive elements in LW was about $10 \%$ higher in D oaks, although this difference was not statistically significant. In the case of D oaks, narrower rings (less than $800 \mathrm{~m}$ ) contained only a small portion of LW, which was mainly composed of LW vessels and tracheids. If fibers were present, they were not arranged in radial flames, as typical of oaks. LW was even absent in some cases. The negative relation between the percentage of LW conductive area and TRW that was observed in D oaks has also been reported by Phelps and Workman (1994). These observations suggest that the formation of LW vessels has priority in LW, in comparison with fibers, indicating the precedence of the conductive function over the mechanical, even though LW vessels do not contribute much to conductivity as long as there are conducting EW vessels. However, as a ring-porous species, oak has strongly reduced hydraulic conductivity in early spring because the large vessels in the EW from the past year become embolized either during the summer or during the winter (Bréda and Granier 1996; Hinckley et al. 1979). Early spring, when a new set of EW vessels is forming, is therefore an exception; at that time the ascent of sap takes place via LW vessels, which remain functional for several years (Tyree and Zimmermann 2010). Vessel diameter, area and percentage of conductive area strongly influence the amount of water that can be transported in the living tree, and so the higher proportion of ring 
occupied by conductive elements, the less tissue is available for supporting, strengthening and storage. A decrease in fiber proportion would then decrease the mechanical properties of LW, but the need for additional strength becomes less crucial as the stem increases in diameter (Rao et al. 1997).

The anatomical structure of wood in $Q$. robur, which is closely related to TRW, with different proportions of xylem elements and their morphological characteristics, defines the hydraulic and mechanical properties of wood and hence affects the survival and efficiency of the living tree (Rao et al. 1997). In terms of wood properties, an increase in the size and density of EW vessels have a negative effect on wood density (Leal et al. 2007) indicating that diminished radial growth considerably negatively affects wood properties and quality of oaks.

Relation between the measured anatomical variables in each of the studied oak groups and the Krka River flow TRW and LW density have been proven to be closely linked to environmental conditions and are therefore very useful for climate reconstruction (e.g., Friedrichs et al. 2009). In this study, we have demonstrated that certain wood anatomical variables of $Q$. robur have a potential also in dendrohydrological studies.

The two groups of oaks responded differently to the Krka River flow in the studied period (i.e. 39 years). TRW and LW proportion of D oaks were affected by (mainly maximum) spring and minimum summer flow of the Krka River and were wider if the flow in spring was lower but higher in summer. Since TRW (as well as LW proportion) was negatively related with the conductive area of EW vessels and EW vessel density, these two variables were higher if the spring flow was higher. On the other hand were anatomical variables of W oaks predominantly related to the (mean) summer flow showing its positive relation with tree-ring and LW proportion, but negative with conductive area of EW vessels, EW vessel density and the share of vessels in LW. Thus, in both oak groups were the conductive area of EW vessels and their density undoubtely closely (inversely) related to TRW. This could be explained by almost proportional relationship between TRW and LWW (Rao et al. 1997). Hence, if tree-ring is wider, the proportion of LW is larger and consequently the share of EW vessels and their density decreases. Wimmer (2002) considered that only a few wood-anatomical features have proved to be useful for characterizing the relationship between tree growth and climate, because they are often inter-correlated with more easily obtainable variables, thus providing little new environmental information. According to Tardif and Conciatori (2006), EW vessel features in ring-porous species may be best used to decipher a discontinuous signal related to tree growth, in particular, for understanding tree physiology. At this point, it should be stressed again that, in addition to our small sample size, most dendroecological studies of Quercus spp. have focused on climatic data and not hydrological data and have not been conducted in an area with regular flooding; it is therefore difficult 
to compare our results with their findings. Quercus species are differently adapted to drought (Nardini and Tyree 1999). Q. robur is known to be a water-demanding species and is a regular constituent of floodplain forests. It is generally considered to be one of the most flood-tolerant Quercus spp. with respect to growth and survival; it can endure prolonged periods of flooding due to a better adjustment of leaf biomass production to the hydraulic conductivity of the root system (Ferner 2009; Prpić 2003; Schmull and Thomas 2000). However, prolonged flooding can cause a dramatic decrease in assimilation and transpiration rates (Ferner 2009).

Radial growth of W oaks was stimulated in the summer period (July-August) if the flow was higher. On the other hand, higher flows of the Krka river did not promote the growth of D oaks although they are growing on a non-flooded area. Few studies have been published on growth patterns of bog Q. robur and Q. sessiliflora, which are considered to be sensitive indicators of changing ecological conditions because they grow under temporarily extremely wet site conditions (Leuschner et al. 2002; Pilcher 1996; Sass-Klaassen and Hanraets 2006). Suppressed growth of these oaks was probably caused by dramatic hydrological changes resulting in a shortened growth season with an absence of LW (Sass-Klaassen and Hanraets 2006). Site hydrology seems to play an important role in the growth and population dynamics of oaks from such areas (Leuschner et al. 2002; Sass-Klaassen and Hanraets 2006). Similarly, $Q$. robur decline and dieback in European floodplain forests in recent years occur particularly in areas that have already been stressed by a deteriorating hydrological regime (Hager and Buchleitner 2001; Levanič et al. 2011; Vukelić and Rauš 2001). The lowered water table makes the rehabilitation of the forests extremely difficult because the roots of the saplings in early years draw water from the soil layer, which is watered from above. However, when roots grow below these layers in later years, they cannot reach the depressed water table and consequently perish (Haraszthy 2001). The reduced growth of $Q$. robur, often resulting in tree death, may be associated with differences in TRW, EW vessel area and carbon isotope discrimination (Levanič et al. 2011). Investigating xylem anatomy as a time series at the intra- and inter-annual level has already been demonstrated to be a promising approach in tree biology and climate change research, particularly if complemented by physiological and ecological studies (Fonti et al. 2010). Specific anatomical features, such as EW vessel size and density, have been shown to be reliable ecological indicators that contain environmental information different from that stored in TRW (e.g. Tardif and Conciatori 2006, Fonti et al. 2009, 2010; George et al. 2002; SassKlaassen et al. 2011). Interestingly, we found no relation of the Krka River flow with other anatomical variables (size of the EW vessels and their density in EW) of D and W oaks, suggesting that they probably depend on other environmetal/climatic factors. Nevertheless, floods are often directly, but very locally, recorded in the cambium, 
resulting in an extreme reduction in EW vessel area in Quercus spp. (George et al. 2002; Sass-Klaassen et al. 2010).

Site-specific soil regimes often play a role in limiting moisture availability in oak forests (Charton and Harmon 1973; Estes 1970). Tree-ring time series contain a lot of information about environmental conditions and their impact on the growth of trees. Our study clearly shows that the hydrologic information stored in wood anatomical features may vary, even within the same forest stand, and largely depends on the micro-environment. Reduced wood increments of D oaks suggest that growth conditions are less favourable in the non-flooded areas of Krakovo lowland forest. Decreasing growth curves are among the most obvious growth-related characteristics of the diminishing vitality of trees, which is not only a species-specific but also a site-specific feature (Bigler et al. 2004). The vitality of $Q$. robur from Krakovo forest might vary, implying a link between the health state of oaks from lowland forest in Slovenia and hydrological conditions. Our research suggests that oaks from the non-flooded areas might experience more physiological stress and contain different hydrological information. Thus, trees intended for hydrological or climatological reconstruction must be carefully selected in order to avoid the possibility of error and potential loss of information in the reconstruction. However, this hypothesis is speculative and for deeper investigations a larger number of sampled trees should be included from several areas in the Krakovo forest. For present study, no data on groundwater were collected but these will be considered in further studies in order to understand better the way $Q$. robur uses water resources and could complement the results presented in this study by bringing new insight into the survival mechanisms of trees in conditions of changed water availability.

\section{Acknowledgements}

The authors gratefully acknowledge the help of Špela Jagodic and Robert Krajnc from the Slovenian Forestry Institute in the field and laboratory. In addition, they would also like to thank the anonymous reviewers for their valuable comments and suggestions to improve the quality of the paper. The Slovenian Research Agency supported this work in part through the young researchers' program (Polona Hafner), by P4-0107 and by project L4-9653. 
Bigler C, Gričar J, Čufar K (2004) Growth patterns as indicators of impending tree death in silver fir. Forest Ecol Manag 199:183-190

Biondi F, Waikul K (2004) DENDROCLIM2002:A C++ program for statistical calibration of climate signals in tree-ring chronologies. Comput Geosci 30:303-311

Bréda N, Granier A (1996) Intra- and interannual variations of transpiration, leaf area index and radial growth of a sessile oak stand (Quercus petraea). Ann Sci Forest 53:521-536

Carlquist S (1988) Comparative Wood Anatomy. Springer Verlag, Berlin and Heidelberg

Charton FL, Harmon JR (1973) Dendrochronology in northwestern Indiana. Ann Assoc Am Geogr 63:302-311. doi:10.1111/j.1467-8306.1973.tb00927.x

Cook ER, Holmes RL (1986) Users manual for program ARSTAN. In; Holmes RL, Adams RH, Fritts HC (eds) Tree-ring chronologies of Western North America: California. Eastern Oregon and Northern Great Basin. Laboratory of Tree-Ring Research, University of Arizona, pp 50-65

Čater M (2003) Pendulate oak (Quercus robur L.) crown defoliation - changes on permanent research plots. Ekológia 22:430-443

Čater M, Batič F (2006) Groundwater and light conditions as factors in the survival of pedunculate oak (Quercus robur L.). Eur J Forest Res 125:419-426. doi:10.1007/s10342-006-0134-6

Čater M, Kutnar L, Accetto M (2001) Slovenian lowland and floodplain forests In: Klimo E, Hager H (eds) The floodplain forests in Europe: current situation and perspectives. Brill, Leiden Boston Köln. pp 233-248

Čater M, Levanič T (2004) Increments and environmental conditions in two slovenian pedunculate-oak forest compexes. Ekológia 23:353-365

Čufar K, De Luis M, Eckstein D, Kajfež-Bojataj L (2008) Reconstructing dry and wet summers in SE Slovenia from oak tree-ring series. Int J Biometeorol 52:607-615

Čufar K, Levanič T (1999a) Progress of dendrochronological research in Slovenia. Dendrochronologia 16-17:173181

Čufar K, Levanič T (1999b) Tree-ring investigations in oak and ash from different sites in Slovenia. Phyton 39:113-116

Eilmann B, Weber P, Rigling A, Eckstein D (2006) Growth reactions of Pinus sylvestris L. and Quercus pubescens Willd. to drought years at a xeric site in Valais, Switzerland. Dendrochronologia 23:121-132

Eilmann B, Zweifel R, Buchmann N, Fonti P, Rigling A (2009) Drought-induced adaptation of the xylem in Scots pine and pubescent oak. Tree Physiol 29:1011-1020

Estes EE (1970) Dendrochronology of black oak (Quercus velutina Lam.), white oak (Quercus alba L.), and shortleaf pine (Pinus echinata Mill.) in the Central Mississippi Valley. Ecol Monogr 40:295-317

Ferner E (2009) Effects of flooding on the carbon metabolism of beech (Fagus sylvatica, L.) and oak (Quercus robur, L.). Dissertation, Albert-Ludwigs-Universität Freiburg im Breisgau

Fonti P, von Arx G, García-González I, Eilmann B, Sass-Klaassen U, Gärtner H, Eckstein D (2010) Studying global change through investigation of the plastic responses of xylem anatomy in tree rings. New Phytol 185:4253

Fonti P, García-González I (2004) Suitability of chestnut earlywood vessel chronologies for ecological studies. New Phytol 163:77-86 
Fonti P, Treydte K, Osenstetter S, Frank D, Esper J (2009) Frequency-dependent signals in multi-centennial oak vessel data. Palaeogeogr, Palaeoclimatol, Palaeoecol 275:92-99

Friedrichs DA, Neuwirth B, Winiger M, Löffler J (2009) Methodologically induced differences in oak site classifications in a homogeneous tree-ring network. Dendrochronologia 27:21-30

Gasson P (1987) Some implications of anatomical variations in the wood of pedunculate oak (Quercus robur L.). including comparisons with common beech (Fagus sylvatica L.). IAWA Bull 8:149-166

George SS, Neilsen E, Conciatori F, Tardif J (2002) Trends in Quercus macrocarpa vessel areas and their implications for tree-ring paleoflood studies. Tree-Ring Res 58:3-10

Gozdnogospodarski načrt gozdnogospodarske enote Krakovo 2006 - 2015 (Forest management plan for Forest Management Unit Krakovo 2006 -2015) (2006) Zavod za gozdove Slovenije, območna enota Brežice. Brežice, $129 \mathrm{p}$.

Guilley É, Hervé J-C, Huber F, Nepveu G (1999) Modelling variability of within-ring density components in Quercus petraea Liebl. with mixed-effect models and simulating the influence of contrasting silvicultures on wood density Ann For Sci 56:449-458

Hager H, Buchleitner E (2001) The floodplain forests along the March and Thaya rivers in Austria. In: Klimo E, Hager H (eds) The floodplain forests in Europe: current situation and perspectives. Brill, Leiden Boston Köln. pp 51-66

Haraszthy L (2001) The floodplain forest in Hungary. In: Klimo E, Hager H (eds) The floodplain forests in Europe: current situation and perspectives. Brill, Leiden Boston Köln. pp 17-24

Hinckley TM, Dougherty PM, Lassoie JP, Roberts JE, Teskey RO (1979) A severe drought: impact on tree growth, phenology, net photosynthetic rate and water relations. Am Mid Nat 102:307-316

Kadunc A (2010) Kakovost, vrednostne značilnosti in produkcijska sposobnost sestojev doba in gradna v Sloveniji $=$ Quality, value characteristics and productivity of Pedunculate and Sessile oak stands in Slovenia. Gozd Vestn $68: 217-226$

Kaiser HF (1992) On the invariance of the sum of coefficients alpha for factors under orthogonal rotation. Psychol Rep 70:545-546. doi:10.2466/pr0.1992.70.2.545

Klimo E, Hager H (2001) Executive summary. In: Klimo E, Hager H (eds) The floodplain forests in Europe: current situation and perspectives. Brill, Leiden Boston Köln. pp vii

Leal S, Nunes E, Pereira H (2008) Cork oak (Quercus suber L.) wood growth and vessel characteristics variations in relation to climate and cork harvesting. Eur J Forest Res 127:33-41. doi:10.1007/s10342-007-0180-8

Leal S, Sousa VB, Pereira H (2007) Radial variation of vessel size and distribution in cork oak wood (Quercus suber L.). Wood Sci Technol 41:339-350. doi:10.1007/s00226-006-0112-7

Lebourgeois F, Cousseau G, Ducos Y (2004) Climate-tree-growth relationships of Quercus petraea Mill. stand in the Forest of Bercé ("Futaie des Clos", Sarthe, France) Ann For Sci 61:361-372. doi:10.1051/forest:2004029

Lei H, Milota MR, Gartner BL (1996) Between- and within-tree variation in the anatomy and specific gravity of wood in Oregon white oak (Quercus garryana Dougl.). IAWA J 17:17

Leuschner HH, Sass-Klaassen U, Jansma E, Baillie MGL, Spurk M (2002) Subfossil European bog oaks: population dynamics and long-term growth depressions as indicators of changes in the Holocene hydro-regime and climate. Holocene 12:695-706. doi:10.1191/0959683602hl584rp

Levanič T (1993) Vpliv melioracij na debelinsko rast in prirastek črne jelše, ozkolistnega jesena in doba v Prekmurju (Effects of hydromelioration on diameter growth and increment of black alder, ash and oak in Slovene Prekmurje). Zb Gozdar Lesar 42:7-65 
Levanič T, Čater M, McDowell NG (2011) Associations between growth, wood anatomy, carbon isotope discrimination and mortality in a Quercus robur forest. Tree Physiol 31:298-308

Nardini A, Tyree MT (1999) Root and shoot hydraulic conductance of seven Quercus species. Ann For Sci 56:371377

Phelps JE, Workman EC (1994) Vessel area studies in white oak (Quercus alba L.). Wood Fiber Sci 23:315-321

Pilcher JR (1996) Dendrochronological insights into past oak growth. Ann For Sci 53:663-671

Pilcher JR, Baillie MGL (1980) Eight modern oak chronologies from England and Scotland. Tree-Ring Bull 40:4558

Prpić B (2003) Utjecaj tehničkih zahvata u prostoru na nizinske šume (The effect of technical operations in the area of lowland forests). Šumarski list 5-6:230-235

Quinn G, Keough M (2002) Experimental design and data analysis for biologists. Cambridge University Press

Rao RV, Aebischer DP, Denne MP (1997) Latewood density in relation to wood fibre diameter, wall thickness, and fibre and vessel percentages in Quercus robur L. IAWA J 18:127-138

Sass-Klaassen U, Hanraets E (2006) Woodlands of the past - The excavation of wetland woods at ZwolleStadshagen (the Netherlands): Growth pattern and population dynamics of oak and ash. Geol Mijnbouw - N J G 86:61-71

Sass-Klassen U., Sabajo C, Belien E, den Ouden J (2010) Effect of experimental flooding on vessel area of pedunculate oak and common ash - a matter of timing. In: Mielikäinen K, Mäkinen H, Timonen M (eds) WorldDendro 2010: the 8th international conference on dendrochronology. Rovaniemi, Finland, pp 155.

Sass-Klaassen U, Sabajo CR, den Ouden J (2011) Vessel formation in relation to leaf phenology in pedunculate oak and European ash. Dendrochronologia 29:171-175. doi:10.1016/j.dendro.2011.01.002

Schmull M, Thomas MF (2000) Morphological and physiological reactions of young deciduous trees (Quercus robur L., Q. petraea [Matt.] Liebl., Fagus sylvatica L.) to waterlogging. Plant Soil 225:227-242. doi:10.1023/A:1026516027096

Tardif JC, Conciatori F (2006) Influence of climate on tree rings and vessel features in red oak and white oak growing near their northern distribution limit, southwestern Quebec, Canada. Can J Forest Res 36:2317-2330. doi:10.1139/x06-133

Tyree MT, Zimmermann MH (2010) Xylem structure and the ascent of sap. Springer-Verlag, Berlin Heidelberg New York

Vukelić J, Rauš Đ (2001) The lowland forest of Croatia: 101-127. In: Klimo E, Hager H (eds) The floodplain forests in Europe: current situation and perspectives. Brill, Leiden Boston Köln. pp 101-126

Wimmer R (2002) Wood anatomical features in tree-rings as indicators of enviromental change. Dendrochronologia 20:21-36

Zhang SY (1997) Variations and correlations of various ring width and ring density features in European oak: implications in dendroclimatology. Wood Sci Technol 31:63-72

Zhang SY, Zhong Y (1991) Effect of growth rate on specific gravity of East-Liaoning oak (Quercus liaotungensis) wood. Can J Forest Res 21:255-260. doi:10.1139/x91-031

Žibert F (2006) Sestojna zgradba v pragozdnem rezervatu Krakovo in gospodarskem gozdu (Stand structure in virgin forest reserve Krakovo and managed forest). Thesis, University of Ljubljana 
Table 1. Measured anatomical variables in the tree-rings of W and D oaks. EW - earlywood, LW - latewood.

Table 2. Average values and standard deviation (SD) of measured anatomical variables in W and D oaks. TRW tree-ring width, EW - earlywood, LW - latewood, T ave ves - Average tangential diameter of EW vessels, R ave ves - Average radial diameter of EW vessels, EW ves area - Average values of EW vessel area, EW ves/Meas area

- Conductive area of EW vessels, EW ves/EW area - Conductive area in EW, No of ves/Meas area - EW vessel density, No of ves/EW area - EW vessel density in EW, LW portion ves/Fibre - Proportion of LW vessels according to the proportion of fibers in LW. 
Figure 1. Average monthly flow of the Krka River (Qs, Qvp, Qnp). Qnp - minimal monthly rate of flow (daily average) $[\mathrm{m} 3 / \mathrm{s}]$, Qs - average monthly rate of flow [m3/s], Qvp - maximal monthly rate of flow (daily average) $[\mathrm{m} 3 / \mathrm{s}]$

Figure 2. Krka River flow variables (Qs, Qvp, Qnp) calculated at annual scales. Qnp - minimal monthly rate of flow (daily average) [m3/s], Qs - average monthly rate of flow [m3/s], Qvp - maximal monthly rate of flow (daily average) $[\mathrm{m} 3 / \mathrm{s}]$.

Figure 3. Schematic illustration of the measured anatomical parameters in each tree-ring. EW - earlywood, LW fibers in LW.

Figure 6. Anatomical characteristics and relations among the variables are explained by PC1 and PC3 in D oaks (a, c) and by PC2 and PC4 in W oaks (b, d). EW - earlywood, LW - latewood, T ave ves - Average tangential 
diameter of EW vessels, R ave ves - Average radial diameter of EW vessels, EW ves area - Average values of EW vessel area, EW ves/Meas area - Conductive area of EW vessels, EW ves/EW area - Conductive area in EW, No of ves/Meas area - EW vessel density, No of ves/EW area - EW vessel density in EW, LW portion ves/Fibre Proportion of LW vessels according to the proportion of fibers in LW.

Figure 7. Correlation between PCA scores and the Krka River flow data at annual and seasonal (from previous autumn to summer) time scales. PC1 and PC3 are mainly related to D oaks (a, c) whereas PC2 and PC4 to W oaks (b, d). The horizontal line indicates significance level at 95\%. Qnp - minimum flow, Qs - mean flow, Qvp maximum flow, AUT-1 - previous autumn, WIN - winter, SPR - spring, SUM - summer, EW - earlywood, LW - latewood, T ave ves - Average tangential diameter of EW vessels, R ave ves - Average radial diameter of EW vessels, EW ves area - Average values of EW vessel area, EW ves/Meas area - Conductive area of EW vessels, EW ves/EW area - Conductive area in EW, No of ves/Meas area - EW vessel density, No of ves/EW area - EW vessel density in EW, LW portion ves/Fibre - Proportion of LW vessels according to the proportion of fibers in LW. 
610

Table 1. Measured anatomical variables in the tree-rings of W and D oaks. EW - earlywood, LW - latewood. 612

\begin{tabular}{ll}
\hline Code of the variable & Description of the measured variable (unit) \\
\hline TRW & Width of tree-ring $(\mu \mathrm{m})$ \\
T ave ves & Average tangential diameter of EW vessels $(\mu \mathrm{m})$ \\
R ave ves & Average radial diameter of EW vessels $(\mu \mathrm{m})$ \\
EW ves area & Average values of EW vessel area ( $\mu \mathrm{m} 2)$ \\
EW ves/Meas area & Conductive area of EW vessels (Percentage of cross-sectional area \\
& occupied by EW vessels) $100 *(\%)$ \\
EW ves/EW area & Conductive area in EW (Percentage of EW cross-sectional area occupied \\
& by EW vessels) $100 *(\%)$ \\
No of ves/Meas area & EW vessel density (Number of EW vessels per square millimetre of \\
& measured area of the tree-ring) $(\mathrm{n} \% \mathrm{~mm} 2)$ \\
No of ves/EW area & EW vessel density in EW (Number of EW vessels per square millimetre of \\
EW measured area) $(\mathrm{n} \% \mathrm{~mm} 2)$ \\
LW portion ves/Fibre
\end{tabular}


616 Table 2. Average values and standard deviation (SD) of measured anatomical variables in W and D oaks. TRW 617 tree-ring width, EW - earlywood, LW - latewood, T ave ves - Average tangential diameter of EW vessels, R ave 618 ves - Average radial diameter of EW vessels, EW ves area - Average values of EW vessel area, EW ves/Meas area 619 - Conductive area of EW vessels, EW ves/EW area - Conductive area in EW, No of ves/Meas area - EW vessel 620 density, No of ves/EW area - EW vessel density in EW, LW portion ves/Fibre - Proportion of LW vessels according to the proportion of fibers in LW.

622

\begin{tabular}{lcccc}
\hline & \multicolumn{2}{c}{ D Oaks } & \multicolumn{2}{c}{ W Oaks } \\
Variable & Average & SD & Average & SD \\
\hline TRW $(\mu \mathrm{m})$ & 1196.31 & 593.94 & 2642.05 & 887.52 \\
T ave ves $(\mu \mathrm{m})$ & 293.40 & 58.11 & 275.56 & 55.48 \\
R ave ves $(\mu \mathrm{m})$ & 308.47 & 60.59 & 332.44 & 65.95 \\
EW ves area $(\mu \mathrm{m} 2)$ & 71753.86 & 14874.27 & 72239.30 & 10252.00 \\
EW ves/Meas area $(\%)$ & 28.868 & 10.595 & 17.633 & 5.364 \\
EW ves/EW area $(\%)$ & 50.085 & 5.525 & 46.086 & 5.823 \\
No of ves/Meas area $\left(\mathrm{n}^{\circ} / \mathrm{mm} 2\right)$ & 4.092 & 1.778 & 2.242 & 0.833 \\
No of ves/EW area $\left(\mathrm{n}^{\circ} / \mathrm{mm} 2\right)$ & 7.057 & 1.493 & 6.293 & 1.138 \\
LW portion ves/Fibre $(\%)$ & 65.38 & 20.87 & 55.90 & 9.13 \\
LW portion $(\%)$ & 42.38 & 19.85 & 61.71 & 10.63 \\
\hline
\end{tabular}

623 


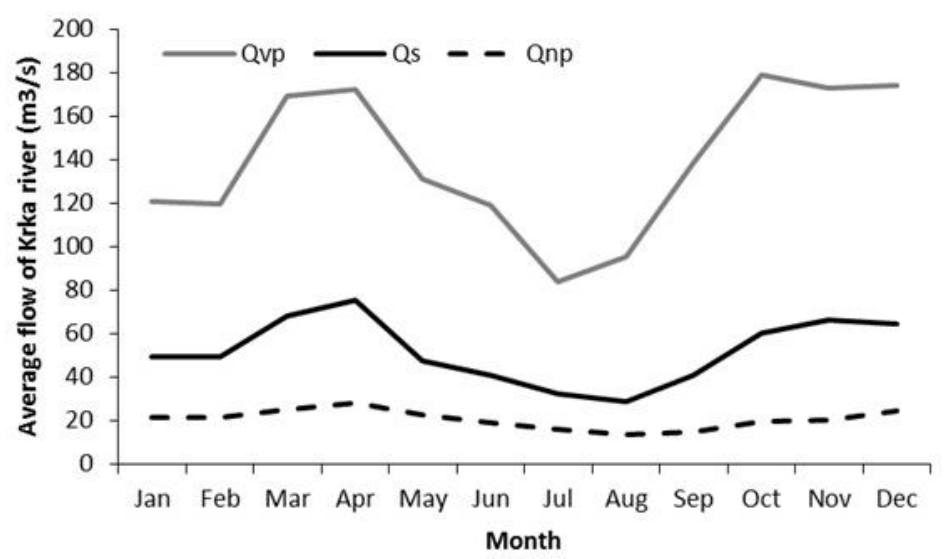

629

630 Figure 1. Average monthly flow of the Krka River (Qs, Qvp, Qnp). Qnp - minimal monthly rate of flow (daily average) $[\mathrm{m} 3 / \mathrm{s}]$, Qs - average monthly rate of flow [m3/s], Qvp - maximal monthly rate of flow (daily average) $[\mathrm{m} 3 / \mathrm{s}]$.

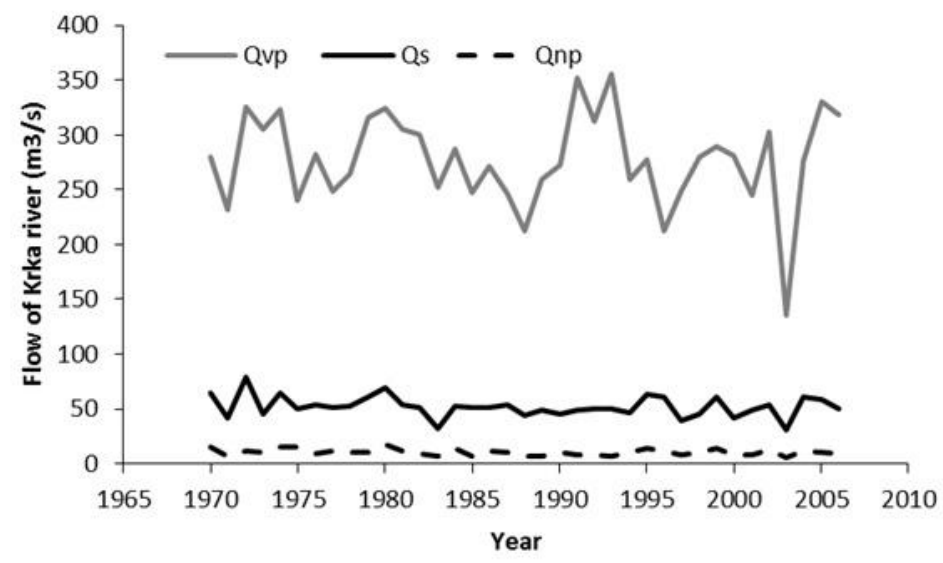

634

Figure 2. Krka River flow variables (Qs, Qvp, Qnp) calculated at annual scales. Qnp - minimal monthly rate of (daily average) $[\mathrm{m} 3 / \mathrm{s}]$. 


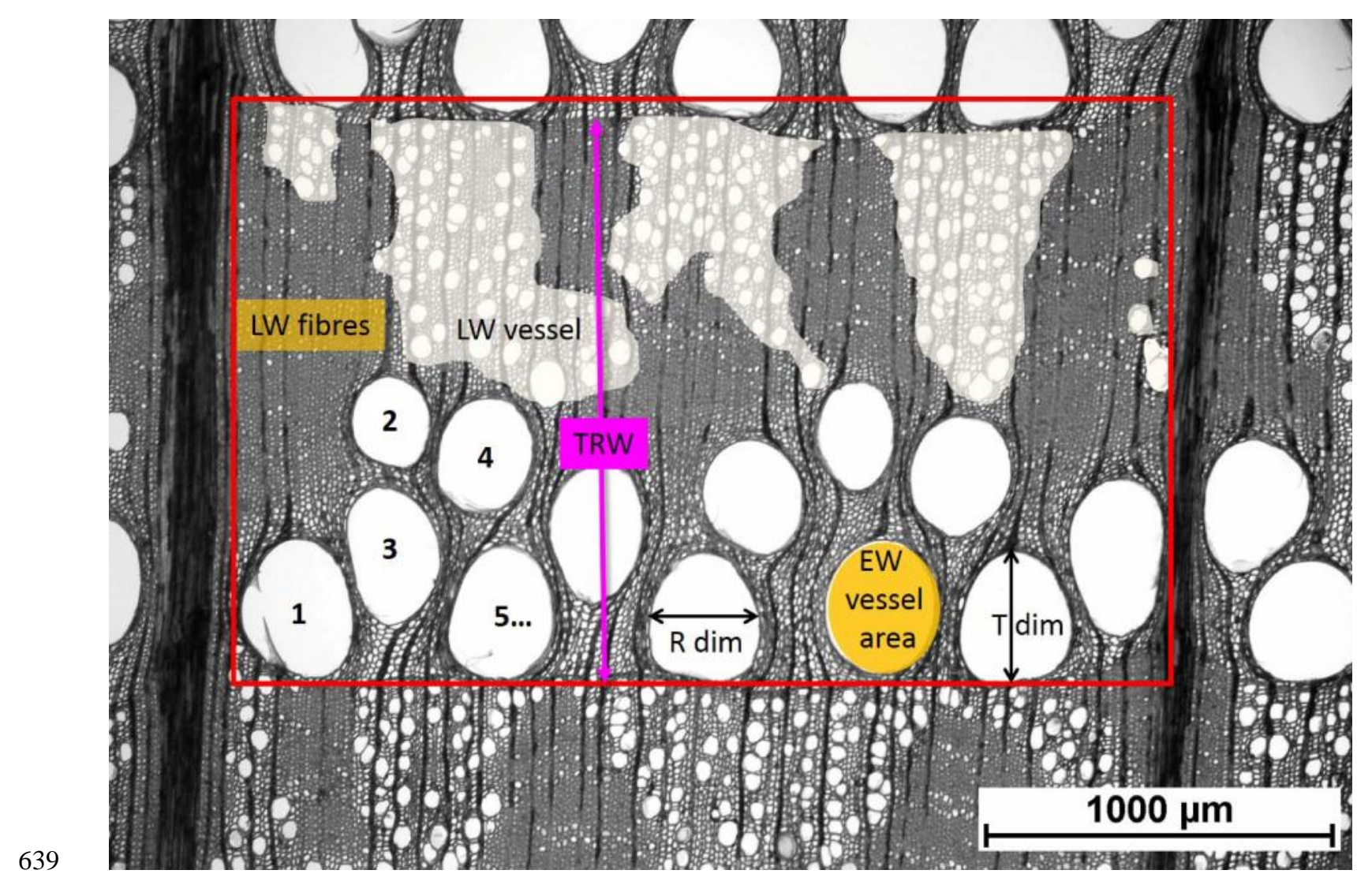

640 Figure 3. Schematic illustration of the measured anatomical parameters in each tree-ring. EW - earlywood, LW

641 - latewood, T dim - tangential dimension of EW vessel, R dim - radial dimension of EW vessel. 

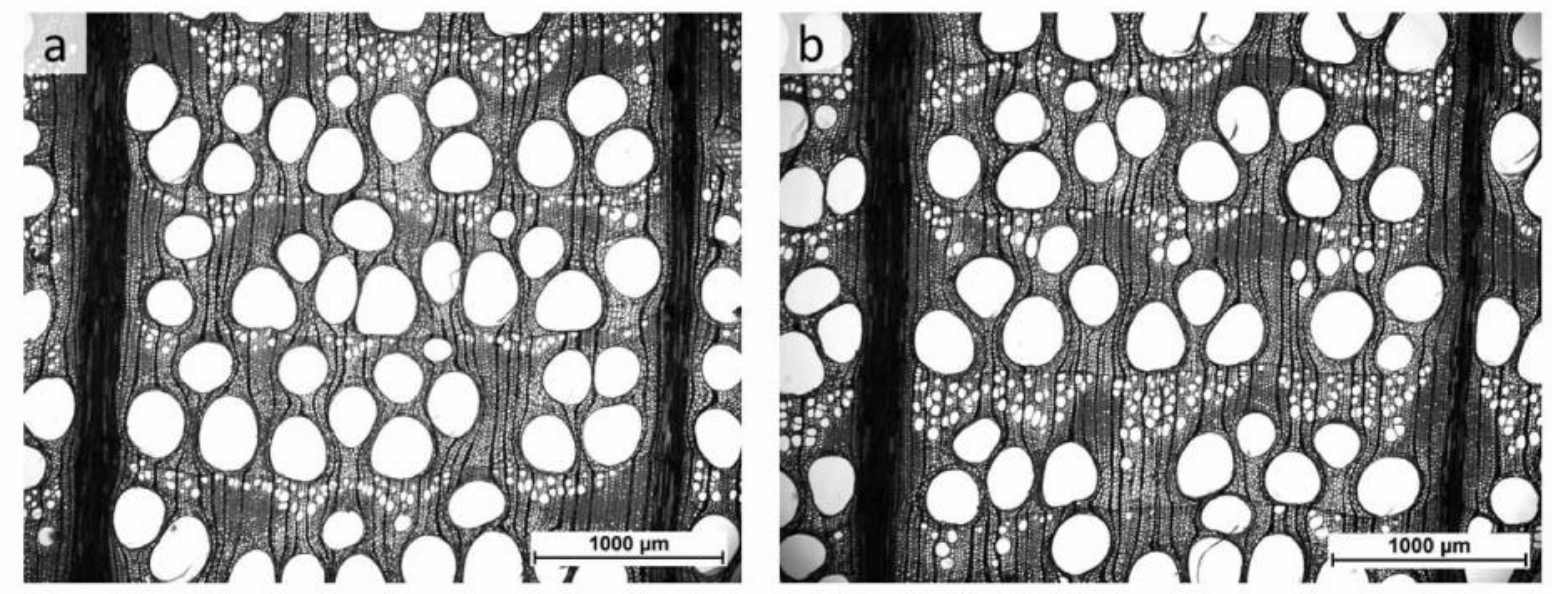

643
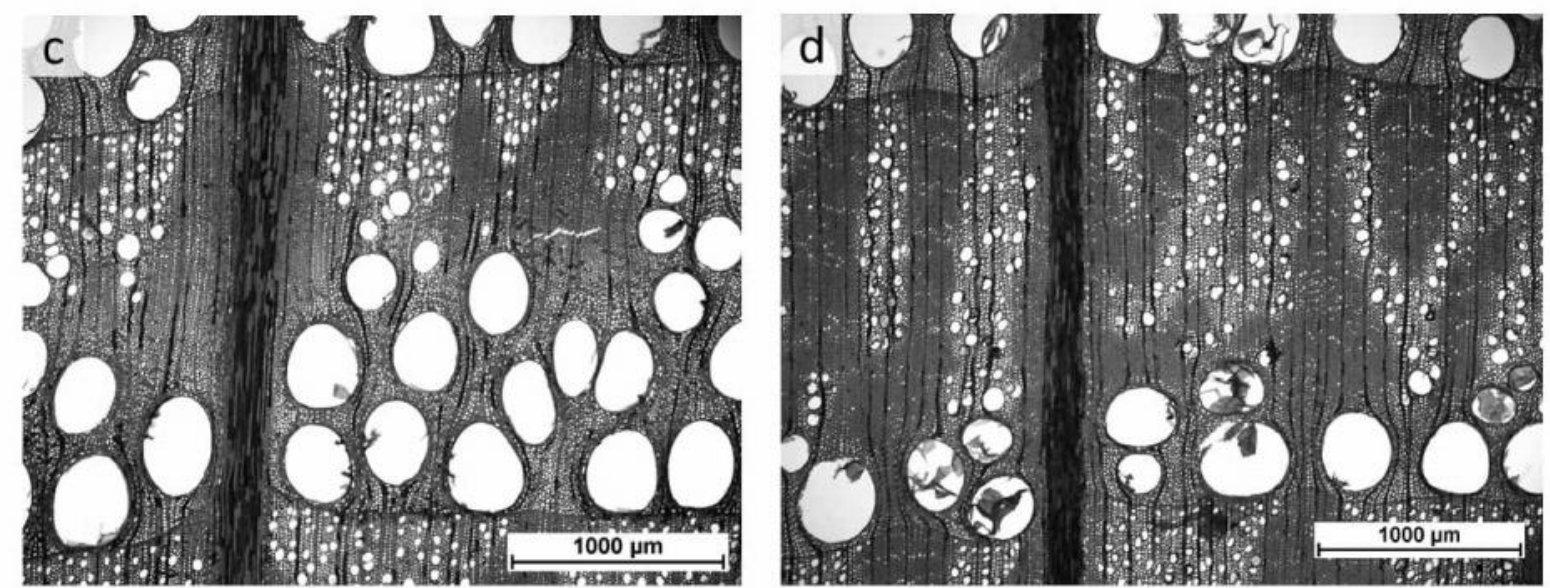

644

Figure 4. Similar TRW (a-b and c-d) with different anatomical structure. a - Tree-ring of D oak with higher

proportion of EW; b - Tree-ring of D oak with higher proportion of LW; c - Tree-ring of W oak with higher

646 proportion of EW; d - Tree-ring of W oak with higher proportion of LW. EW - earlywood, LW - latewood. 

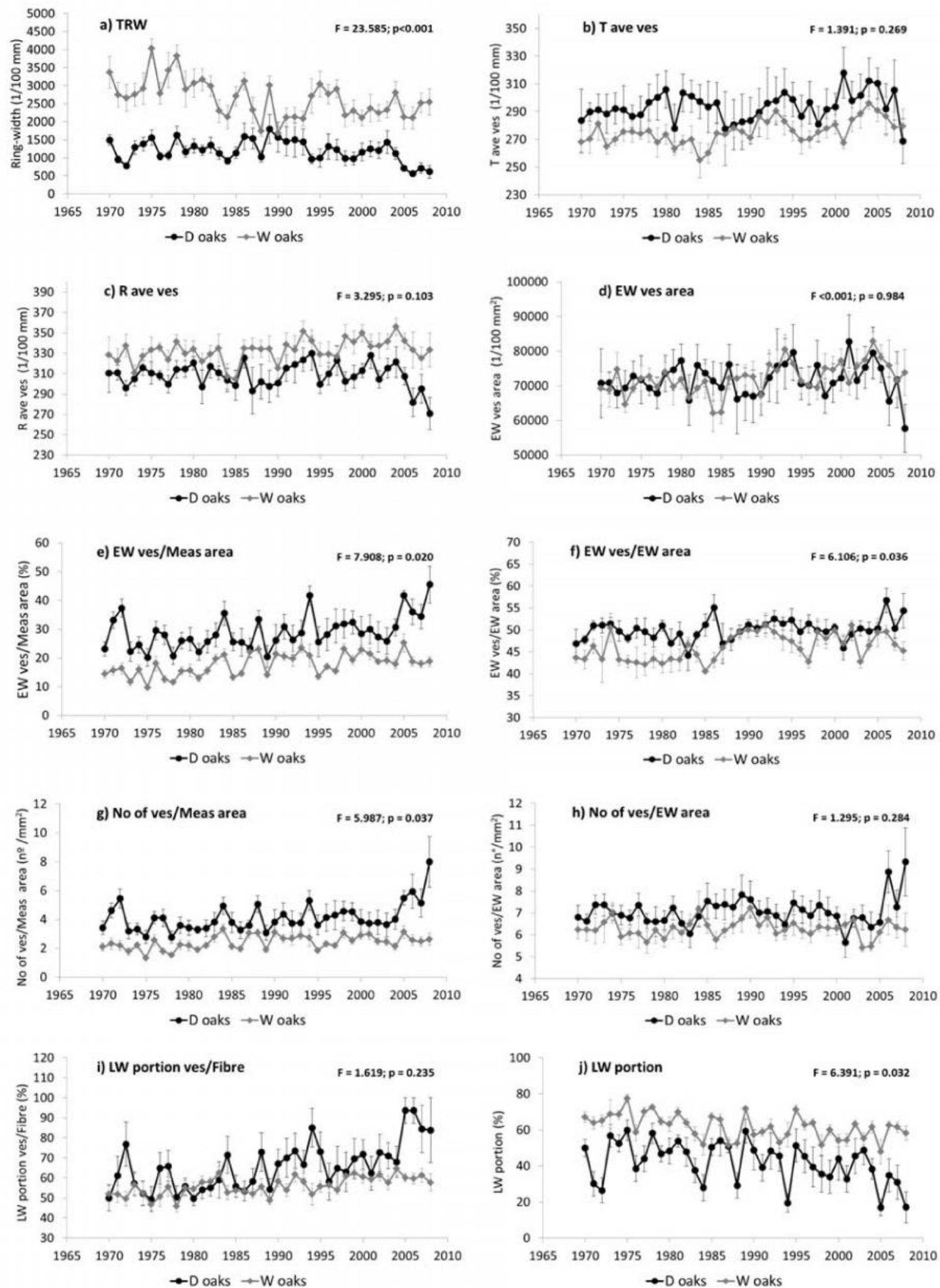

649 Figure 5. Time series of of tree-ring widths and wood-anatomical characteristics of W and D oaks for the period 1970-2008 showing differences in some parameters (TRW, EW ves/Mean area, EW ves/EW area, No of ves/Meas area and LW portion), but similarities in others (T ave ves, R ave ves, EW ves area, No of ves/ EW area and LW 

test for differences between $\mathrm{W}$ and D oaks in all the measured anatomical variables. TRW - tree-ring width, EW - earlywood, LW - latewood, T ave ves - Average tangential diameter of EW vessels, R ave ves - Average radial diameter of EW vessels, EW ves area - Average values of EW vessel area, EW ves/Meas area - Conductive area of EW vessels, EW ves/EW area - Conductive area in EW, No of ves/Meas area - EW vessel density, No of ves/EW area - EW vessel density in EW, LW portion ves/Fibre - Proportion of LW vessels according to the proportion of fibers in LW.

659 

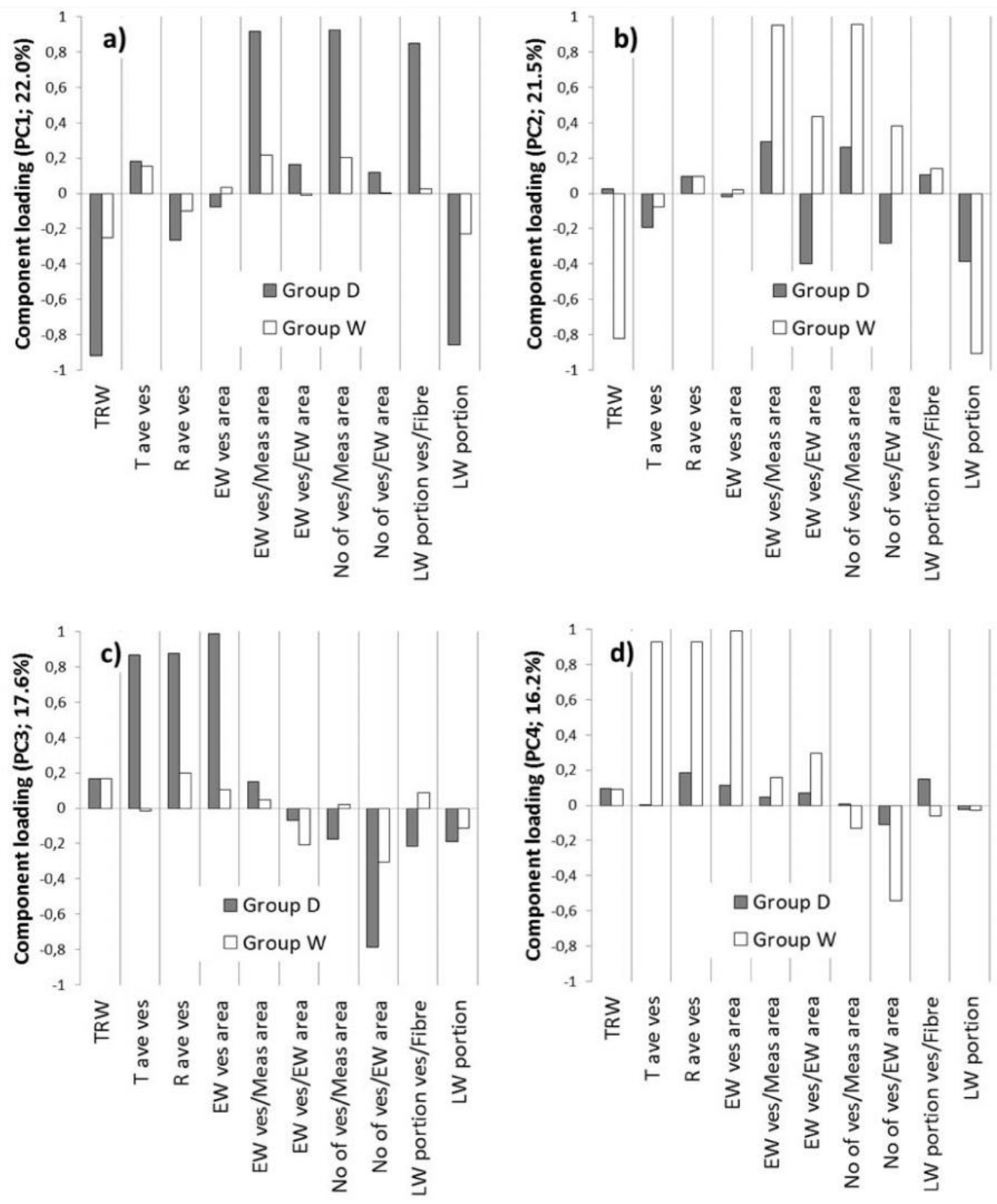

660

Figure 6. Anatomical characteristics and relations among the variables are explained by $\mathrm{PC} 1$ and PC3 in D oaks (a, c) and by PC2 and PC4 in W oaks (b, d). EW - earlywood, LW - latewood, T ave ves - Average tangential diameter of EW vessels, R ave ves - Average radial diameter of EW vessels, EW ves area - Average values of EW vessel area, EW ves/Meas area - Conductive area of EW vessels, EW ves/EW area - Conductive area in EW, No of ves/Meas area - EW vessel density, No of ves/EW area - EW vessel density in EW, LW portion ves/Fibre Proportion of LW vessels according to the proportion of fibers in LW. 

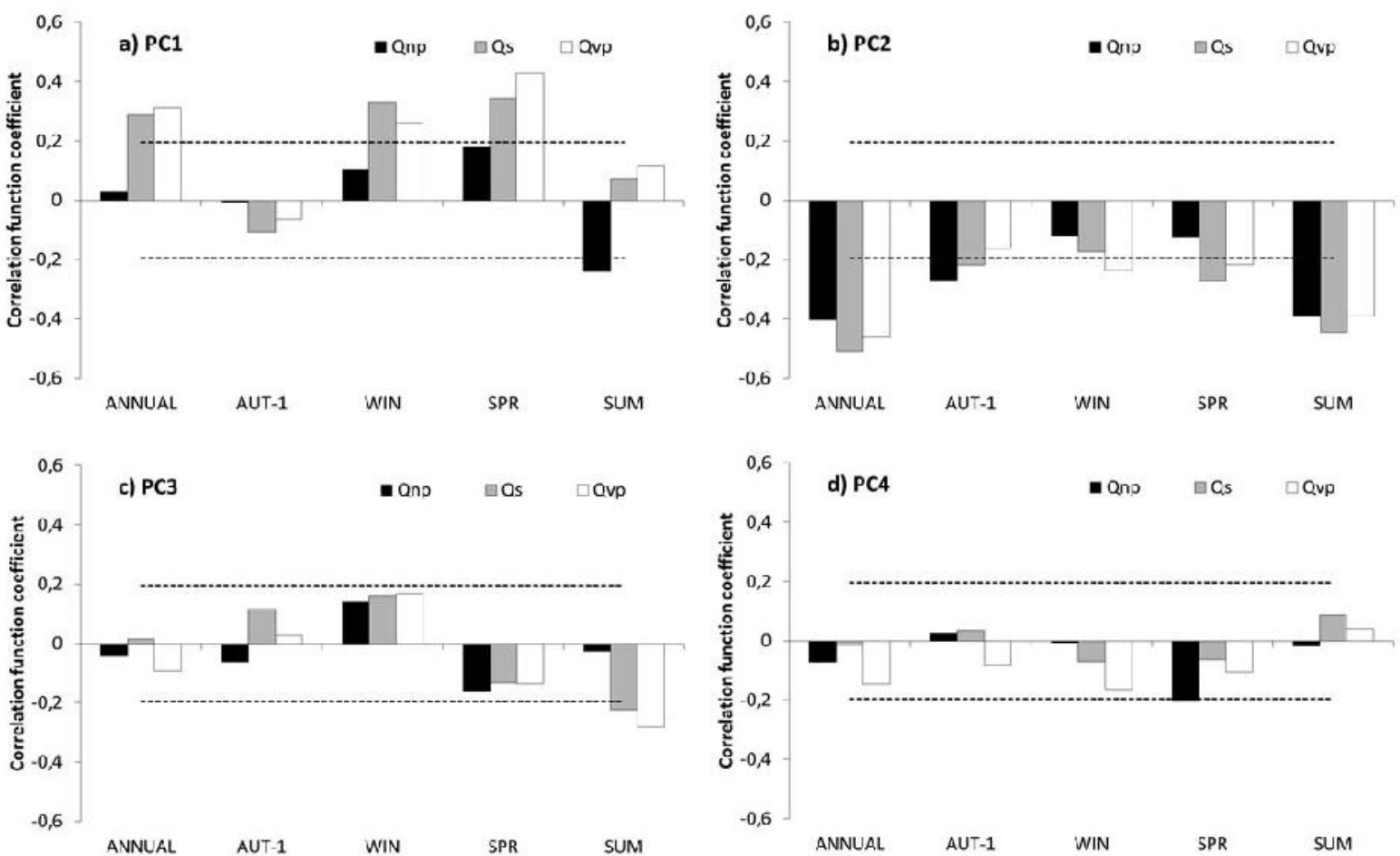

Figure 7. Correlation between PCA scores and the Krka River flow data at annual and seasonal (from previous autumn to summer) time scales. PC1 and PC3 are mainly related to D oaks (a, c) whereas PC2 and PC4 to W oaks (b, d). The horizontal line indicates significance level at 95\%. Qnp - minimum flow, Qs - mean flow, Qvp maximum flow, AUT-1 - previous autumn, WIN - winter, SPR - spring, SUM - summer, EW - earlywood, LW - latewood, $\mathrm{T}$ ave ves - Average tangential diameter of EW vessels, R ave ves - Average radial diameter of EW vessels, EW ves area - Average values of EW vessel area, EW ves/Meas area - Conductive area of EW vessels, EW ves/EW area - Conductive area in EW, No of ves/Meas area - EW vessel density, No of ves/EW area - EW vessel density in EW, LW portion ves/Fibre - Proportion of LW vessels according to the proportion of fibers in LW. 